\title{
Treatment technologies of liquid and solid wastes from two-phase olive oil mills
}

\author{
By Rafael Borja*, Francisco Raposo and Bárbara Rincón
}

\author{
Instituto de la Grasa (CSIC), Avda. Padre García Tejero, 4, 41012-Sevilla, Spain \\ * Corresponding author: R. Borja (FAX: 34-95-4691262; Telephone: 34-95-4689654; \\ E-mail: rborja@cica.es)
}

\section{RESUMEN}

Tecnologías de tratamiento de los efluentes líquidos y residuos sólidos resultantes del proceso de elaboración del aceite de oliva por centrifugación en dos fases

Durante los últimos 10 años el proceso de elaboración de aceite de oliva ha sufrido importantes cambios en los equipos utilizados para la separación del aceite del resto de componentes. El más reciente ha sido la introducción del decanter o centrífuga horizontal de dos fases para la separación del aceite de oliva de la mezcla constituida por la fracción sólida vegetal y agua de vegetación. Por tanto, el sistema de elaboración por centrifugación en dos fases genera tres residuos diferentes: 1) aguas de lavado de aceitunas; 2 ) aguas de lavado de aceite obtenidas en la centrífuga vertical y 3) residuos sólidos con un elevado contenido en humedad procedente del decanter. Entre otras ventajas, el proceso de dos fases también reduce considerablemente el consumo de agua de proceso. Esta tecnología ya se ha introducido en el $90 \%$ de las almazaras españolas. Por tanto, los nuevos efluentes líquidos resultantes del proceso en dos fases están constituidos por la mezcla de los efluentes (1) y (2), generándose cantidades del orden de $0.25 \mathrm{l} / \mathrm{kg}$ de aceitunas procesadas. De manera adicional, se genera un nuevo residuo sólido (orujo húmedo o "alperujo") con una elevada concentración de materia orgánica, lo que le confiere un alto poder contaminante, dificultando su manipulación y aprovechamiento mediante los métodos tradicionales aplicados al orujo convencional de tres fases.

En este trabajo se detallan las características principales y propiedades de los efluentes líquidos y residuos sólidos resultantes del proceso de elaboración del aceite de oliva en dos fases, comparándose con las características de los alpechines y orujos tradicionales procedentes del sistema de tres fases. También se resumen las ventajas e inconvenientes del sistema de dos fases. Entre los tratamientos que se detallan para la depuración de las aguas de lavado mezcla destacan los procesos aerobios en reactores de mezcla completa y lodos activados, con los que se alcanzan elevadas eficiencias de depuración, obteniéndose las constantes cinéticas de los mismos para diferentes condiciones operacionales. También se describen los resultados más relevantes obtenidos en el proceso de digestión anaerobia de estas aguas de lavado utilizando reactores de lecho fluidizado e híbridos, detallándose el comportamiento operacional, estabilidad, eficiencias de depuración y coeficientes de rendimiento en metano alcanzados. Igualmente se detallan otros métodos de tratamiento del alperujo, tales como métodos oxidativos (utilizando diferentes oxidantes químicos) y fisicoquímicos (utilizando diferentes coagulantes y floculantes). A mismo tiempo, se describe la digestibilidad anaerobia del alperujo utilizando diferentes concentraciones de sustrato como alimento, detallándose algunos estudios cinéticos y balances de masa que permiten reproducir el comportamiento del reactor, así como determinados modelos simplificados que permiten estudiar las etapas de hidrólisis, acidogénesis y metanogénesis en el proceso de digestión anaerobia en una y dos etapas del alperujo. Finalmente, se reseñan otros métodos para el tratamiento y aprovechamiento de este residuo, tales como compostaje, obtención de alcoholes, manitol, y otros compuestos de valor añadido, tales como monosacáridos, oligosacáridos, arabinosa y glucosa, así como furfural y carbón activo.

PALABRAS-CLAVE: Aceite de oliva - Alperujo - Efluentes líquidos - Sistema en dos fases - Tecnologías de tratamiento.

\section{SUMMARY}

Treatment technologies of liquid and solid wastes from two-phase olive oil mills

Over the last 10 years the manufacture of olive oil has undergone important evolutionary changes in the equipment used for the separation of olive oil from the remaining components. The latest development has been the introduction of a two-phase centrifugation process in which a horizontally-mounted centrifuge is used for a primary separation of the olive oil fraction from the vegetable solid material and vegetation water. Therefore, the new two-phase olive oil mills produce three identifiable and separate waste streams. These are: 1) the wash waters from the initial cleansing of the fruit; 2 ) the wash waters from the secondary centrifuge and 3 ) the aqueous solid residues from the primary centrifugation. As well as offering process advantages they also reduce the water consumption of the mill. The introduction of this technology was carried out in $90 \%$ of Spanish olive oil factories. Therefore, the new twophase olive mill effluents (TPOME) are made up of the mixture of effluents (1) and (2), the total volume of TPOME generated being around $0.25 \mathrm{l} / \mathrm{kg}$ of olives processed. In addition, the solid residue (two-phase olive pomace, TPOP) has a high organic matter concentration giving an elevated polluting load and it cannot be easily handled by traditional technology which deals with the conventional three-phase olive cake.

So, this paper aims to report the main features and characteristics of TPOME, and of TPOP, as compared to the classical olive mill wastewater (OMW) and olive cake derived from the three-phase manufacturing process. The advantages and disadvantages of the two-phase decanting process will be summarized. Among the treatments reported for TPOME, aerobic processes in completely mixed and activated sludge reactor showed high COD removal efficiencies. Kinetic constants of the aerobic processes were also compared at different operational conditions. The report also includes the following findings: assays of anaerobic digestion of wastewaters from the washing of olives, of olive oil and the two together using fluidised-beds and hybrid reactors; the kinetics, performance, stability, purification efficiencies and methane yield coefficients; other purifying 
methods for TPOME treatment including oxidation (with different chemical oxidants) and physico-chemical treatments (using different coagulants and flocculants); the anaerobic digestibility of TPOP using different influent substrate concentrations; kinetic studies of anaerobic digestion of TPOP and mass balances to predict the behaviour of the reactor and simplified kinetic models for studying the hydrolysis, acidogenic and methanogenic steps of one and two-stage anaerobic digestion of TPOP. Finally, other methods for treatment and use of TPOP were mentioned, including composting, production of alcohols, mannitol, and other added - value compounds such as monosaccharides, oligosaccharides, arabinose and glucose. Furfural and activated carbons were also produced from TPOP and included in the report.

KEY-WORDS: Liquid effluents - Olive oil - Treatment technologies - Two-phase olive pomace - Two-phase system.

\section{INTRODUCTION}

Olives are one of main crops in terms of cultivation surfaces across the Mediterranean basin. There are approximately 750 million productive olive trees worldwide, which occupy a surface of 7 million ha. The annual worldwide production of edible oils and olive oil has been estimated at 8 million and 1.743 million metric tons respectively, from 25,000 olive-mills (Niaounakis and Halvadakis, 2004). The Mediterranean area alone provides $98 \%$ of the total surface area for olive tree culture and total productive trees, and $97 \%$ of the total olive production. The largest olive oil producers are Spain, Italy, Greece, Turkey and Tunisia and to a lesser extent Portugal, Morocco and Algeria. Spain is the leader as regards the total culture surface $(2,121,181 \mathrm{ha})$ and the number of productive trees $(180,000,000)$. Olives are also cultivated in California (USA), Australia and Argentina (Niaounakis and Halvadakis, 2004). However, the olive oil market is fluctuating, as it is influenced by a number of climatic, socio-economic, political and cultural factors (Alba et al., 2001).

The evolution of modern technology for olive oil extraction has affected the industrial sector depending directly on the by-products obtained. The traditional three-phase continuous centrifugation process for olive oil extraction was introduced in the 1970s, notably to increase the processing capacity and extraction yield and to reduce labour. This three-phase manufacturing process of olive oil usually yields an oily phase $(20 \%)$, a solid residue (30\%) and an aqueous phase $(50 \%)$, the latter coming from the water content of the fruit. Such water, combined with that used to wash and process the olives, make up the so-called "olive mill wastewater" (OMW) and also contains soft tissues from olive pulp and a very stable oil emulsion (Borja et al., 1995a). This process generates a total volume of traditional OMW of around 1.25 litres $/ \mathrm{kg}$ of olives processed. Consequently, the three-phase centrifugation process caused an increase in the average mill size, a decrease in the total number of mill, increased water consumption (the original threephase technology needs from 1.25 to 1.75 times more water than press extraction) and increased production of wastewaters (Alba et al., 1995).

\section{THREE-PHASE OLIVE MILL WASTEWATERS (OMW)}

The OMW composition is not constant either qualitatively or quantitatively and it varies according to cultivation soil, harvesting time, the degree of ripening, olive variety, climatic conditions, the use of pesticides and fertilizers and the duration of aging (Niaounakis and Halvadakis, 2004). The threephase OMW is characterized by the following special features and components (López-Camino, 1993; González-López et al., 1994):

- Intensive violet-dark brown to black in color.

- Specific strong olive oil smell.

- High degree of organic pollution. (Chemical oxygen demand - COD - values up to $220 \mathrm{~g} / \mathrm{l}$ ).

- pH between 3 and 6 (slightly acidic).

- High electrical conductivity.

- High content of polyphenols (0.5-24 g/l).

- High content of solid matter.

Table I summarizes the maximum and minimum values of the main contamination related parameters of OMW. The substantial range in the reported values can be only partially justified by differences in the organic content of the olives due to variety and the degree of ripening and their nutrient (TKN and total-P) content as affected by the availability of soil nutrients.

Another salient feature of this type of waste is its facility for fermenting while in storage, which gives rise to substantial changes in composition, yet does not necessarily result in its complete biodegradation (Tsonis et al., 1987).

\subsection{Main organic compounds}

OMW contain sugars levels in the order of $1.6 \%$ $4 \%(w / v)$ and they constitute up to $60 \%$ of the dry substance and comprise, in decreasing amounts, fructose, mannose, glucose, saccharose, traces of sucrose and some pentoses (Fernández-Bolaños et al., 1983).

The phenolic compounds contained in OMW can be classified roughly in two groups (Hamdi, 1992). The first group contains simple phenolic compounds, not autoxidated tannins (low molecular weight) and flavonoids. The flavonoids are polyphenolic compounds possessing 15 carbon atoms. The main flavonoids detected in OMW are apigenin, luteolin and quercetin (Maestro-Durán et al., 1991; Servili et al., 1999). The main phenolic acids are syringic acid, p-hydroxyphenylacetic acid, vanillic acid, veratric acid, caffeic acid, protocatechuic acid, $p$-coumaric acid and cinnamic acid (Balice and Cera, 1984). The polyphenols of 
Table I

Maximum and minimum values of the main contamination-related parameters of OMW

\begin{tabular}{lcc}
\hline Parameter & Maximum & Minimum \\
\hline $\mathrm{pH}$ & 6.7 & 4 \\
Redox potential $(\mathrm{mV})$ & -330 & -80 \\
Conductivity $(\mathrm{mS})$ & 16 & 8 \\
Density (g/l) & 1.100 & 1.016 \\
Color (U pt-Co) & 180000 & 52270 \\
Turbidity (UNT) & 62000 & 42000 \\
Suspended solids $(\mathrm{g} / \mathrm{l})$ & 9 & 1 \\
Settleable solids $(\mathrm{ml} / \mathrm{l} \mathrm{h})$ & 250 & 10 \\
Biochemical oxygen demand, BOD $(\mathrm{mg} / \mathrm{l})$ & 110000 & 35000 \\
Chemical oxygen demand, COD $(\mathrm{mg} / \mathrm{l})$ & 170000 & 45000 \\
Oxygen uptake rate, OUR (mg/l h) & 100 & 50 \\
Total bacteria $\left(10^{6} \mathrm{col} / \mathrm{ml}\right)$ & 5 & - \\
Total yeasts and fungi & 5 & - \\
\hline
\end{tabular}

the second group, which contain darkly colored polymers, result from the polymerisation and autooxidation of the phenolic compounds of the first group. The color of the OMW depends on the ratio between the two groups of polyphenols. The presence of these recalcitrant organic compounds constitutes one of the major obstacles in the detoxification and purification of OMW (Hamdi, 1992; Borja et al., 1995a). In addition, some of these phenols are responsible for several biological effects, including antibiosis (Rodríguez et al., 1988) and phytotoxicity (Capasso et al., 1992).

\subsection{Inorganic compounds}

The content, composition and physico-chemical status of metal cations and inorganic anions present in three-phase OMW has been reported in literature (Arienzo and Capasso, 2000). The following concentrations of cations and anions were found in these wastewaters:

* Cations: $\mathrm{K}^{+}, 9.80 \mathrm{~g} / \mathrm{l} ; \mathrm{Mg}^{2+}, 1.65 \mathrm{~g} / \mathrm{l} ; \mathrm{Ca}^{2+}: 1.35 \mathrm{~g} / \mathrm{l}$; $\mathrm{Na}^{+}, 0.162 \mathrm{~g} / \mathrm{l} ; \mathrm{Fe}^{2+}, 0.033 \mathrm{~g} / \mathrm{l} ; \mathrm{Zn}^{2+}, 0.0301$ $\mathrm{g} / \mathrm{l} ; \mathrm{Mn}^{2+}, 0.0091 \mathrm{~g} / \mathrm{l} ; \mathrm{Cu}^{2+}, 0.0098 \mathrm{~g} / \mathrm{l}$.

*Anions: $\mathrm{Cl}^{-}, 1.3 \mathrm{~g} / \mathrm{l} ; \mathrm{H}_{2} \mathrm{PO}_{4}^{-}, 0.85 \mathrm{~g} / \mathrm{l} ; \mathrm{F}^{-}, 0.53 \mathrm{~g} / \mathrm{l}$; $\mathrm{SO}_{4}^{2-}, 0.42 \mathrm{~g} / \mathrm{l} ; \mathrm{NO}_{3}{ }^{-}, 0.0109 \mathrm{~g} / \mathrm{l}$.

As can be seen, $\mathrm{K}^{+}$was the predominant cation, while the prevailing anion proved to be $\mathrm{Cl}^{-}$followed by the biacid phosphate, $\mathrm{H}_{2} \mathrm{PO}_{4}^{-}$, which was in this form as a consequence of the acid $\mathrm{pH}$. With respect to other anions, $\mathrm{NO}_{3}{ }^{-}$ions were present at very low concentrations.

\subsection{Microbial content of OMW}

OMW contains a variable high number of bacteria, yeasts and fungi. Among the strains identified were several species of Acinetobacter, Pseudomonas and Enterobacter. However, much of the microbial activity was represented by 71 strains, showing different metabolic patterns (Niaounakis and Halvadakis, 2004).

Millan et al. (2000) studied the microbial composition of OMW from four disposal ponds. Among the fungal members, 12 different genera (Acremonium, Alternaria, Aspergillus, Chalara, Fusarium, Lecytophora, Paecilomyces, Penicillium, Phoma, Phycomyces, Rhinocladiella and Scopulariopsis) were found. Members of five genera (Chalara, Fusarium, Paecilomyces, Penicillium and Scopulariopsis) were widely distributed, and were able to grow efficiently in undiluted OMW as a sole source of nutrients. Strains of Fusarium, Paecilomyces, Penicillium and Scopulariopsis showed a marked capacity for OMW detoxification, depleting its antibacterial activity almost completely.

\subsection{Environmental problems of OMW}

The annual OMW production of Mediterranean olive-growing countries is estimated to ranging from 7 million to over 30 million $\mathrm{m}^{3}$. This huge divergence of results can partly be explained by the fact that the production of olives varies from one year to another due to weather conditions and plagues that can affect the olive trees (Niaounakis and Halvadakis, 2004). The average total production amounts approximately to $10-12 \times 10^{6} \mathrm{~m}^{3} /$ year and occurs over a brief period of the year (November-March). Spain produced $20 \%$ of the OMW of the Mediterranean basin $\left(2-3 \times 10^{6} \mathrm{~m}^{3} /\right.$ year $)$ before the implantation of the two-phase extraction process in most of the Spanish olive oil factories, which represented an equivalent pollution of $10-16 \times 10^{6}$ inhabitants in the short milling period (Cabrera et al., 1996).

The efforts to find a solution to the OMW problem are more than 50 years old (Fiestas and Borja, 1992). There are many different types of 
processes that have been tested, which can be classified into three separate general categories:

1. Detoxification processes:

a. Physical processes.

b. Thermal processes.

c. Physico-chemical processes.

d. Biological processes

e. Combination of processes

2. Recycling and recovery of valuable components.

3. Production system modification.

None of the detoxification techniques on an individual basis allow the problem of disposal of OMW to be solved to a complete and exhaustive extent, effectively and in an ecologically satisfactory way. At the present state of OMW treatment technology, industry has shown little interest in supporting any traditional process (physical, chemical, thermal or biological) on a wide scale. This is because of the high investment and operational costs, the short duration of the production period (3-5 months) and the small size of the olive mills (Boari et al., 1984).

Several techniques also exist, which make it possible for some potentially valuable organic compounds contained in OMW to be extracted. These techniques use specific solvents and ultrafiltration/reverse osmosis techniques, which in turn, require complex chemical facilities to be available.

\section{THE TWO-PHASE OLIVE OIL MANUFACTURING PROCESS}

The pollution incidents due to the uncontrolled discharge of OMW, and problems associated with the evaporation ponds put pressure on finding a solution for the rapidly growing environmental problems (Alba et al., 2001). On the other hand, the failure to develop a suitable and economical effluent wastewater treatment technology for OMW has lead manufacturers of technology to develop the "ecological" two-phase process, which uses no process water, and delivers oil as the liquid phase and a very wet olive cake (two-phase olive pomace -TPOP-) as the solid residue. This technology has attracted special interest where water supplies are restricted and/or aqueous effluent must be reduced (Niaounakis and Halvadakis, 2004).

In the two-phase process a horizontally mounted centrifuge is used for primary separation of the olive oil fraction from the vegetable solid material and vegetation water (Alba et al., 2001). The resultant olive oil is further washed to remove residual impurities before finally being separated from this wash water in a vertical centrifuge. Therefore, the two-phase olive mills produce three identifiable and separate waste streams (Raposo et al., 2003). These are:

1) The wash waters generated during the initial cleansing of the fruit.
2) The aqueous solid residues generated during the primary centrifugation (TPOP).

3) The wash waters from the secondary centrifuge generated during the washing and purification of virgin olive oil.

Hence, the final two-phase olive mill effluents (TPOME) are made up of one part of the first stream and three parts of the third stream, the total volume of TPOME generated being around 0.25 $\mathrm{l} / \mathrm{kg}$ of olives processed (Alba et al., 2001).

Spain was the first country where the two-phase system was used and from there this new technology was installed around the world. The twophase decanting reduces the water requirements. Nevertheless it has created a new solid residue, TPOP, which requires further investigation to find out how it must be handled.

Decanters based on the two-phase process were initially designed and developed by Westfalia Separator and subsequently by several other companies (Alpha Laval, Sweden; Pieralisi, Italy, etc.). The performance of such a decanter was evaluated in comparison to a traditional threephase extraction process and was found to produce olive oil in similar yields to the three-phase process, but of a superior quality in terms of polyphenol and diphenol content (Niaounakis and Halvadakis, 2004). The higher contents of total phenols and diphenols were attributed to the increased amount of added water used in the three-phase decanter which diluted the aqueous phase and thus reduced the oil phenol content as a result of partitioning and of the higher solubility of these compounds in water. Oils produced by the traditional three-phase process were approximately half as stable as the two-phase oils, as determined by the Rancimat method (Aparicio et al., 1999).

Several studies have been carried out to ascertain the influence of the two- and three-phase centrifugal decanters employed in the olive process on oil yield, the composition and quality of virgin olive oil (Di Giovacchino et al., 2001 and 2002). In one of these studies tests were performed in an olive-mill equipped with centrifugal decanters at two- and three-phase on a homogeneous lot of three olive varieties (Coratina, Nebbio and Grosse di Cassano) at an industrial level (Ranalli and Angerosa, 1996). The results showed that the twophase centrifuge frequently yielded higher oil outputs. Furthermore, as the vegetation water was not separated from the stone, the amount of liquid effluent produced was much lower. This goes towards solving the age-old and very difficult problems connected with the production of this highly polluting outflow. However, the resulting olive by-product is in sludge form, with about 55\%-70\% of moisture content while traditional olive cake from three-phase centrifuges has only around $40 \%-45 \%$ humidity (Alba et al., 2001), making the industrial recovery of the residual oil difficult and expensive. Furthermore, the semisolid by-product was characterized by higher values of the pulp/stone 
ratio, as well as the greater weight produced. It was also shown that virgin oils extracted with the two different decanters do not differ in free fatty acids, peroxide value and ultraviolet absorption. The extraction system did not modify qualitatively the phenolic composition of virgin olive oils obtained with the two different centrifugal decanters. However, virgin oils obtained by the two-phase mode showed a greater concentration of phenolic compounds than the homologous oils obtained by the three-phase mode (Cert et al., 1996; Piacquadio et al., 1998). In general, olive oils obtained by the two-phase system were of a far higher quality, mainly due to their higher oxidative stability and better organoleptic characteristic, so that they are wholly comparable to those extracted by pressing or filtering. In addition, the significant reduction of processing costs, as well as the lower utilization of hot water and electrical energy, must also be emphasized.

Two-phase decanting has the following advantages over three-phase decanting:

- The construction of the two-phase scroll centrifuge is less complicated and thus is more reliable in operation and less expensive than the three-phase decanter.

- During operation of the three-phase scroll centrifuge the separated oil and water may be remixed; volatile compounds from the vegetation water may cause a sticky deposit on the centrifuge.

- The throughput of the two-phase centrifuge in relation to the oil quantity is higher because no additional water is required to produce the pulp. Energy consumption is also reduced as a result of the lower processing quantity.

- Oil produced by the two-phase centrifuge is of higher quality; in particular, it has higher oxidation stability and better organoleptic characteristics.

- The operating costs are lower. Water utilization in the olive mill decreases considerably. are:

\section{The disadvantages of two-phase decanting}

- The two-phase process, although it produces no olive mill wastewater as such, generates the wash waters derived from the initial cleansing of the fruit and during the washing and purification of virgin olive oil. In addition, it combines the olive vegetation water that is generated with the solid waste to produce a single effluent stream in semi-solid form. This doubles the amount of "solid" waste (TPOP or "alperujo") requiring disposal, and it cannot be composted or burned without some form of expensive pre-treatment.

- TPOP has a moisture content in the range of $55 \%-70 \%$, while traditional cake has only around $40 \%-45 \%$ humidity in three-phase centrifuges. This increased amount of moisture, together with the sugars and fine solids that in the three-phase system were contained in OMW give TPOP a doughy consistency and makes transport, storage and handling difficult -it can not be piled and must be kept in large ponds.

- TPOP is characterized by higher values of the pulp/stone ratio, as well as the greater weight produced.

- This two-phase technology transfers the problem of disposing of the olive-mill waste from the mill to the seed-oil refineries. TPOP, prior to oil solvent extraction, must be dried with considerably higher energy requirements than in the three-phase continuous oil production process, making the industrial recovery of the residual oil difficult and expensive.

\subsection{Two-phase olive mill effluents (TPOME)}

Over the last 10 years the manufacture of olive oil has undergone important changes. As has already been commented, the latest development has been the introduction of a two-phase centrifugation process, in which a horizontallymounted centrifuge is used for separation of the olive oil fraction. Two-phase olive mill effluents (TPOME) are made up of a mixture of the wash waters generated during the initial washing of olives and the wash waters generated during the purification of virgin olive oil. Table II shows the average volumes of the wastewaters generated in the three- and two-phase olive oil extraction processes during the different steps of both manufacturing processes. In addition, Table III summarizes the oil, solids and COD contents of the wastewaters generated in the above-mentioned steps of these olive oil extraction processes (Alba et al., 2001).

As can be seen in Table II, the three-phase manufacturing process generates a total volume of traditional OMW of around $1.25 \mathrm{l} / \mathrm{kg}$ of olives processed. On the other hand, in the two-phase process, the total volume of effluents (TPOME) generated is reduced to around $0.25 \mathrm{l} / \mathrm{kg}$ of processed olives. The organic matter content of these effluents is up to thirty times lower than that observed in the classical OMW resulting from the three-phase extraction process. Therefore, although the TPOME have a qualitative composition similar to that observed in OMW, its concentration is much lower because most of the organic compounds from vegetation water remain in the TPOP.

However, the washing of olives prior to the olive oil manufacturing process is a common practice within the two-phase process, especially when the fruits come from the soil. The effluents from the washing of olives normally contain remains of soil and powder, as well as small amounts of inorganic fertilizers, traces of phytosanitary products or pesticides and oil as a consequence of broken 
Table II

Average volumes of the wastewaters generated in the different steps of the three- and two-phase olive oil extraction processes

\begin{tabular}{lcc}
\hline Effluent (I/kg olives processed) & Three-phase process & Two-phase process \\
\hline Washing of olives & 0.09 & 0.05 \\
Horizontal centrifuge & 0.90 & 0.00 \\
Washing of olive oil (vertical centrifuge) & 0.20 & 0.15 \\
General cleaning & 0.05 & 0.05 \\
\hline Total effluents & $\mathbf{1 . 2 4}$ & $\mathbf{0 . 2 5}$ \\
\hline
\end{tabular}

olives. As can be seen in Tables II and III, the amounts of the wash waters derived from the washing of olives and their content in organic matter are lower than those obtained in the washing of olive oil.

In July 2002, the "Confederación Hidrográfica del Guadalquivir" of the Spanish "Ministerio de Medio Ambiente" made it obligatory to segregate the two effluents (washing waters from olives and oil), thus imposing the same restrictions as those destined for irrigation, which must meet the following requirements:

$\mathrm{pH}=6-9$; Suspended solids $<600$ ppm; $\mathrm{BOD}_{5}<$ 2000 ppm; COD < 2500 ppm; limitation for spreading on the terrain: $30 \mathrm{~m}^{3} / \mathrm{Ha}$ every 7 days (MartínezNieto et al., 2004).

Tables IV and V summarize the main features and composition of wash waters generated during the washing of olives and wash waters from the purification of olive oil respectively, obtained in some Spanish olive oil factories from the Cordoba and Jaen provinces (Spain).

As can be seen in Table IV, virtually all wash waters from the initial washing of olives comply with the above-mentioned regulation (Martínez-Nieto et al., 2004). Only one sample has a pH value lower than 6 . The suspended solids content is always lower than $600 \mathrm{ppm}$ and only two samples show COD values higher than those permitted in this Regulation, while the $\mathrm{BOD}_{5}$ values were lower than those established in all cases. In addition, most of the total solids present are of mineral type because the percentage of ashes was always higher than the percentage of organic matter.
In contrast to this, the wash waters generated during the purification of olive oil do not comply with the afore-mentioned Regulation. The COD values were higher than the Regulation limit values in all cases. Their higher concentration in organic matter is due to the high content in organic compounds such as phenolic compounds, substances characterized by its antioxidant and recalcitrant character to its microbial degradation. Table VI shows the phenolic content of some of these wash waters (Martínez-Nieto et al., 2004). As can be seen, values as high as $373 \mathrm{ppm}$ were found in these effluents. The phenolic content of this wastewater depends on the degree of ripening of the fruit as well as on the volume of water used in the washing process, this parameter being vital and determinant in any of the treatment processes to be applied for its purification.

Some phytosanitary compounds have been found in some of the above-mentioned wash waters of olives as can be seen in Table VII. However, the low concentrations observed create no problems when these effluents are used for irrigation. In addition, these compounds are easily removed when aerobic treatments are applied (MartínezNieto et al., 2004).

\subsubsection{Aerobic treatments of TPOME}

\section{* Aerobic treatment of wastewaters from the} washing of olives

An aerobic treatment of wastewaters from the washing of olives prior to the oil production process

Table III

Composition and features of the wastewaters generated in the different steps of the three- and two-phase olive oil extraction processes

\begin{tabular}{|c|c|c|c|c|c|c|}
\hline \multirow[b]{2}{*}{ Effluent } & \multicolumn{3}{|c|}{ Three-phase process } & \multicolumn{3}{|c|}{ Two-phase process } \\
\hline & Solids (\%) & Oil (\%) & COD (g/kg) & Solids (\%) & Oil (\%) & COD $(\mathrm{g} / \mathrm{kg})$ \\
\hline Washing of olives & 0.51 & 0.14 & 7.87 & 0.54 & 0.10 & 0.87 \\
\hline Horizontal centrifuge & 6.24 & 0.96 & 73.82 & 0 & 0 & 0 \\
\hline $\begin{array}{l}\text { Washing of olive oil } \\
\text { (vertical centrifuge) }\end{array}$ & 0 & 0 & 0 & 1.43 & 0.57 & 1.17 \\
\hline Final Effluent & 4.86 & 0.31 & 68.61 & 2.82 & 0.29 & 2.25 \\
\hline
\end{tabular}


Table IV

Composition and features of the wash waters generated during the initial washing of olives corresponding to different Spanish olive oil factories located in the Cordoba $(\mathrm{Co})$ and Jaen $(\mathrm{J})$ provinces

\begin{tabular}{|c|c|c|c|c|c|c|c|}
\hline Factory & pH & $\begin{array}{c}\text { Total } \\
\text { solids (\%) }\end{array}$ & $\begin{array}{c}\text { Ashes } \\
(\%)\end{array}$ & $\begin{array}{c}\text { Organic } \\
\text { matter (\%) }\end{array}$ & $\begin{array}{l}\text { Suspended } \\
\text { solids (\%) }\end{array}$ & $\begin{array}{l}\text { DBO5 } \\
\text { (mg/l) }\end{array}$ & $\begin{array}{c}\text { COD } \\
(\mathrm{mg} / \mathrm{l})\end{array}$ \\
\hline 1 (Co) & 6.34 & 0.27 & 0.17 & 0.10 & - & 500 & 810 \\
\hline 2 (Co) & 5.65 & 0.49 & 0.27 & 0.22 & - & 1820 & 4858 \\
\hline 3 (Co) & 6.22 & 0.23 & 0.07 & 0.15 & 0.005 & 348 & 1640 \\
\hline 4 (Co) & 6.66 & 0.18 & 0.08 & 0.10 & 0.006 & 148 & 222 \\
\hline 5 (J) & 6.02 & 0.28 & 0.21 & 0.07 & 0.006 & 121 & 809 \\
\hline 6 (Co) & 6.03 & 0.87 & 0.53 & 0.34 & - & 1145 & 4494 \\
\hline
\end{tabular}

was previously reported (Borja et al., 1995b). The wastewater was obtained from an olive oil factory located in the south of Spain and its main features and characteristics were: $\mathrm{pH}: 5.8$; COD: $3025 \mathrm{mg} / \mathrm{l}$; soluble COD: $2375 \mathrm{mg} / \mathrm{l}$; $\mathrm{BOD}_{5}$ : $1920 \mathrm{mg} / \mathrm{l}$; total suspended solids: $300 \mathrm{mg} / \mathrm{l}$ and volatile suspended solids: $280 \mathrm{mg} / \mathrm{l}$. The aerobic process was carried out in completely-mixed reactors without recycle at two different temperatures $\left(14^{\circ} \mathrm{C}\right.$ and $\left.28^{\circ} \mathrm{C}\right)$ and hydraulic retention times of $6,12,18,24$ and $30 \mathrm{~h}$. The wastewater from the washing of olives was more efficiently treated at an operating temperature of $28^{\circ} \mathrm{C}$. Over $93 \%$ of soluble COD was removed at a retention time of $6 \mathrm{~h}$ whereas at $14^{\circ} \mathrm{C}, \mathrm{COD}$ removal was only $67 \%$ at the same retention time. A kinetic study of this aerobic process showed that at $28^{\circ} \mathrm{C}$ the maximum specific substrate utilization rate $\left(q_{m}\right)$ was about 11 times faster than at $14^{\circ} \mathrm{C}$. The biokinetic parameters $\mu_{\max }$ (maximum growth rate of microorganisms), $K_{s}$ (saturation constant) and $k_{d}$ (endogenous respiration coefficient) were temperature dependent and showed higher values at $28^{\circ} \mathrm{C}$ than at $14^{\circ} \mathrm{C}$. The overall growth yield $(Y)$ was the same at the different temperatures.

* Aerobic treatment of wash waters derived from the purification of virgin olive oil

A study of aerobic treatment of wash waters derived from the purification of virgin olive oil from the two-phase extraction process using a completely mixed activated sludge (AS) reactor was also previously reported (Borja et al., 1995c). The main characteristics of the wastewater studied were: $\mathrm{pH}$ : 5.5; soluble COD: $2.2 \mathrm{~g} / \mathrm{l} ; \mathrm{BOD}_{5}: 1.4 \mathrm{~g} / \mathrm{l}$; total solids: $1.61 \mathrm{~g} / \mathrm{l}$; volatile solids: $1.38 \mathrm{~g} / \mathrm{l}$; total suspended solids: $0.82 \mathrm{~g} / \mathrm{l}$; volatile suspended solids: $0.69 \mathrm{~g} / \mathrm{l}$. The activated sludge system was operated by combining four input COD concentrations $(700,1200,1700$ and $2200 \mathrm{mg} / \mathrm{l})$ with four values of solids retention time, which ranged between 4.0 and 15.0 days, while the hydraulic retention time varied from 8 to $10 \mathrm{~h}$. The dissolved oxygen concentration (DO) and the operation temperature were maintained at $4.0 \mathrm{mg} / \mathrm{l}$ and $21 \pm 2{ }^{\circ} \mathrm{C}$, respectively. The results obtained indicated that more than $93 \%$ of the input COD concentration can be removed by the various operational conditions. It was found that effluent COD was correlated with input feed strength and it was proportional to the product of feed strength and specific growth rate. The multiple-substrate model of Adams et al. (1975) fitted the data well and could be used predictively to determine effluent COD from a wide range of input substrate concentrations (Borja et al., 1995c).

\subsubsection{Anaerobic treatments of TPOME}

Anaerobic treatment of moderate and high strength wastewaters with high biodegradable content presents a number of advantages in comparison to the classical aerobic processes: a)

Table V

Composition and features of the wash waters from the secondary centrifuge generated during the purification of virgin olive oil corresponding to different Spanish olive oil factories located in the Cordoba (Co) and Jaen $(\mathrm{J})$ provinces.

\begin{tabular}{|c|c|c|c|c|c|c|c|}
\hline Factory & pH & $\begin{array}{c}\text { Total } \\
\text { solids (\%) }\end{array}$ & $\begin{array}{c}\text { Ashes } \\
(\%)\end{array}$ & $\begin{array}{c}\text { Organic } \\
\text { matter (\%) }\end{array}$ & $\begin{array}{l}\text { Suspended } \\
\text { solids (\%) }\end{array}$ & $\begin{array}{l}\text { DBO5 } \\
\text { (mg/l) }\end{array}$ & $\begin{array}{l}\text { COD } \\
(\mathrm{mg} / \mathrm{l})\end{array}$ \\
\hline 1 (Co) & 5.69 & 0.18 & 0.04 & 0.14 & - & 790 & 2874 \\
\hline 2 (Co) & 5.40 & 0.15 & 0.05 & 0.10 & - & 520 & 5935 \\
\hline 3 (Co) & 5.67 & 0.24 & 0.04 & 0.20 & - & 465 & 3805 \\
\hline 4 (Co) & 5.73 & 0.33 & 0.07 & 0.26 & - & 690 & 4230 \\
\hline 5 (J) & 5.11 & 1.47 & 0.05 & 1.42 & - & 915 & 12078 \\
\hline 6 (Co) & 5.16 & 0.59 & 0.10 & 0.49 & - & 790 & 10931 \\
\hline
\end{tabular}


Table VI

Phenolic content of the wash waters from the secondary centrifuge generated during the purification of virgin olive oil corresponding to different Spanish olive oil factories located in the Cordoba (Co) and Jaen $(\mathrm{J})$ provinces.

\begin{tabular}{cc}
\hline Sample & Total phenolic concentration (ppm) \\
\hline $5(\mathrm{~J})$ & 157 \\
$1(\mathrm{Co})$ & 373 \\
$2(\mathrm{Co})$ & 86 \\
\hline
\end{tabular}

quite a high degree of purification with high-organic load feeds can be achieved; b) low nutrient requirements are necessary; c) small quantities of excess sludge are usually produced and finally, d) a combustible biogas is generated. The production of biogas enables the process to generate or recover energy instead of just energy-saving; this can reduce operational costs as compared with other processes such as physical, physicochemical or biological aerobic treatments (Wheatley, 1990).

\section{* Anaerobic digestion of wastewaters from the washing of olives}

A study of the anaerobic digestion process of wastewaters from the washing of olives derived from a two-phase extraction process was carried out at laboratory-scale in a fluidised bed reactor with biomass immobilised on sepiolite at $35^{\circ} \mathrm{C}$ (Borja et al., 1998). The bioreactor operated satisfactorily using influent COD concentrations of 4.5, 3.5, 2.5 and $1.5 \mathrm{~g} \mathrm{COD} / \mathrm{l}$ at hydraulic retention times (HRTs) in the range of 4.5-1.25 days. COD removal efficiencies in the range of $50 \%-90 \%$ were achieved in the reactor when evaluated at organic loading rates of between 0.46 and $2.25 \mathrm{~g} \mathrm{COD/l} \mathrm{d} \mathrm{using} \mathrm{the}$ highest influent substrate concentration $\left(\mathrm{S}_{0}=4.5 \mathrm{~g}\right.$ $\mathrm{COD} / \mathrm{I})$. In this study, COD and volatile fatty acid (VFA) concentrations were increased in parallel with the increase of the organic loading rate, VFA showing a maximum value of $1.55 \mathrm{~g}$ acetic acid/l at the most unfavourable case studied $\left(\mathrm{S}_{0}=4.5 \mathrm{~g}\right.$ $\mathrm{COD} / \mathrm{l}$ and HRT $=1.25 \mathrm{~d}$ ). The increase in effluent VFA concentrations was always counteracted by the high alkalinity values (3440-4670 $\mathrm{mg} \mathrm{CaCO} / \mathrm{l}$ ) which caused the high stability of the process and values of the VFA/alkalinity ratio lower than 0.3-0.5, except for the above-mentioned case, limit value over which the anaerobic process is destabilized. The yield coefficient of methane production was 0.28 I methane STP/g COD removed. The
Michaelis-Menten kinetic model allowed to obtain the values of the maximum substrate utilization rate and kinetic constant for each influent substrate concentration studied. The values of these parameters dropped significantly with decreasing concentration of influent wastewater, showing the highest values for the highest influent substrate concentration used as feed (Borja et al., 1999). The microbial yield coefficient and sludge decay rate coefficient were found to be $0.14 \mathrm{~g} \mathrm{VSS} / \mathrm{g}$ COD and $0.003 \mathrm{~d}^{-1}$, respectively.

A kinetic study of anaerobic digestion of wastewaters from the washing of olives, collected at three different harvest times (December 1992, January and February 1993) was also reported (Borja et al., 1994). Completely mixed batch reactors with biomass immobilised on sepiolite operating at $35^{\circ} \mathrm{C}$ were used in this study. A considerable decrease in the kinetic constants with the harvest time over the substrate concentration range studied (0.5-2.5 g COD/l) was reported. The average values of the kinetic constants obtained were: $1.67,1.13$ and 0.75 days $^{-1}$. Furthermore, the methanogenic activity decreased with the ripening of olives; the observed differences increased when the substrate concentration in the digester increased. The methane yield coefficients ranged between 0.263 (first harvest time) and $0.298 \mathrm{I} \mathrm{CH}_{4} / \mathrm{g}$ COD removed (third harvest time). The elimination of COD exceeded $64 \%$ in all cases.

\section{* Anaerobic digestion of wastewaters derived} from the purification of virgin olive oil

A kinetic study of anaerobic digestion of wastewaters derived from the washing of virgin olive oil was previously reported (Borja et al., 1993). The study was carried out in a completely mixed reactor with biomass immobilized on sepiolite at a concentration of $10.8 \mathrm{~g} \mathrm{VSS} / \mathrm{l}$ operating at $35^{\circ} \mathrm{C}$. The bioreactor worked satisfactorily for hydraulic retention times in the range of 1.1-5.0 days and

Table VII

Phytosanitary compounds found in some wash waters of olives corresponding to two Spanish olive oil factories located in the Cordoba province

\begin{tabular}{lccc}
\hline Sample & Simazine $(\mathbf{p p b})$ & Diuron $(\mathbf{p p b})$ & pp-DDE $(\mathbf{p p b})$ \\
\hline $1(\mathrm{Co})$ & - & 0.11 & 0.06 \\
$2(\mathrm{Co})$ & 0.84 & 16.05 & 0.09 \\
\hline
\end{tabular}


eliminated more than $92 \%$ of the initial COD (3.5 $\mathrm{g} / \mathrm{l})$ in all instances. Guiot's kinetic model was used to determine the macroenergetic parameters of the system, which were found to have a true yield coefficient for the biomass of $0.006 \mathrm{~g} \mathrm{VSS} / \mathrm{g}$ COD and a specific rate of substrate uptake for cell maintenance of $0.072 \mathrm{~g} \mathrm{COD} / \mathrm{g}$ VSS $\mathrm{d}$. In addition, the rate of substrate uptake was correlated with the concentration of biodegradable substrate through an equation of the Michaelis-Menten type.

The performance of a laboratory-scale hybrid reactor, the bottom third of which was occupied by a sludge blanket, the upper two-thirds by submerged clay rings, for treatment of wash waters derived from the purification of olive oil with $\mathrm{COD}$ and $\mathrm{BOD}_{5}$ contents of 8.0 and $5.0 \mathrm{~g} / \mathrm{l}$ respectively, was also reported in literature (Borja et al., 1996). The reactor was operated under mesophilic conditions at different influent substrate concentrations. The HRTs ranged from 0.20 to 1.02 days under normal operating conditions after the start-up. COD removal efficiencies of more than $89 \%$ were achieved at an organic loading rate (OLR) of $8.0 \mathrm{~kg} \mathrm{COD} / \mathrm{m}^{3} \mathrm{~d}$. OLR was gradually increased from 2.6 to $7.1 \mathrm{~kg} \mathrm{COD} / \mathrm{m}^{3}$ d within 16 days but the anaerobic reactor performance did not significantly change. The system can tolerate OLRs as high as $17.8 \mathrm{~kg}$ $\mathrm{COD} / \mathrm{m}^{3} \mathrm{~d}$ with an average COD removal efficiency of $76.2 \%$. Although the reactor was fed by diluted influent, with an average COD of $1030 \mathrm{mg} / \mathrm{l}$, at very high hydraulic loadings (HRT of $4.8 \mathrm{~h}$ ) COD removals over $75 \%$ were achieved.

\section{* Anaerobic digestion of two-phase olive mill effluents (TPOME) made up of the mixture of the wash waters generated during the initial cleansing of olives and the wash waters from the secondary centrifuge generated during the washing and purification of virgin olive oil}

A kinetic study of the batch anaerobic digestion of TPOME using stirred tank reactors with freely suspended biomass and biomass supported on PVC and bentonite was previously reported (in literature) (Raposo et al., 2005). The specific rate constants of the process decreased considerably from 2.59 to 0.14 $\mathrm{d}^{-1}$, from 1.93 to $0.23 \mathrm{~d}^{-1}$ and from 1.52 to $0.17 \mathrm{~d}^{-1}$ for the reactors with suspended biomass (control) and biomass immobilized on PVC and bentonite, respectively, when the COD loadings increased from 1.02 to $14.22 \mathrm{~g}$. This showed an inhibition phenomena in the three reactors studied. The values of the critical inhibitory substrate concentration, theoretical kinetic constant without inhibition and the inhibition coefficient for each reactor were determined using the Levenspiel model.

A simultaneous continuous anaerobic digestion of TPOME was also carried out at laboratory-scale in two stirred tank reactors, one with biomass immobilized on bentonite (B) and the other with suspended biomass used as a control (C). The reactors operated satisfactorily between HRTs of 25 and 5 days, respectively (Raposo et al., 2003).
Soluble COD removal efficiencies in the ranges of $96 \%-80 \%$ and $93 \%-82 \%$ were achieved in reactors B and $\mathrm{C}$, at OLR in the range of between 0.9-4.8 and 0.9-3.8, respectively. Anaerobic degradation occurred under inhibitory conditions. The overall substrate removal rate correlated with the biodegradable substrate concentration through the Andrews kinetic model, from which the maximum substrate removal rate, saturation constant and constant of inhibition $\left(K_{i}\right)$ were calculated. The reactor with immobilized biomass had a better response to inhibitory conditions, probably due to the increase of the sludge age. This proposed model predicted the behaviour of both reactors very accurately showing deviations lower than 5\% between the experimental and theoretical values of substrate removal rates. The same kinetic model allowed the anaerobic degradation of phenolic compounds to be studied, obtaining the corresponding kinetic constants. Finally, a mass (COD) balance around the reactors allowed the methane yield coefficient to be obtained, which gave values of 0.31 and 0.30 I methane/g COD removed for reactors $\mathrm{B}$ and $\mathrm{C}$, respectively. The cell maintenance coefficients obtained by means of this balance were found to be 0.0024 and $0.0036 \mathrm{~g} \mathrm{COD}$ removed/g VSS d, respectively (Raposo et al., 2004).

\subsubsection{Other purifying methods for TPOME}

The utilization of oxidative methods for treatment of TPOME has been reported in literature (MartínezNieto et al., 2003 and 2004). These methods are based on the use of chemical oxidants such as permanganate, hydrogen peroxide $\left(\mathrm{H}_{2} \mathrm{O}_{2}\right)$ or Fenton reactive, after which the effluents can be treated with coagulants such as $\mathrm{FeCl}_{3}$. COD removals higher than $80 \%$ were achieved in the treatment of TPOME containing a COD concentration of $3805 \mathrm{mg} / \mathrm{l}$.

The use of physico-chemical methods for the treatment of TPOME has also been reported previously (Cano-Agüera, 2004). These methods use coagulants and flocculants after a previous homogenisation of the effluents. Later, the treated effluent undergoes a gasification step for the phenolic removal of compounds and, finally, it is subjected to an ozonization process for total purification. COD and BOD removals higher than $90 \%$ were achieved with this treatment. A purification plant based on this method has been constructed in the olive oil factory "Aceites Torres Morente" located at Albolote, Granada (Spain).

\subsection{Two-phase olive pomace (TPOP)}

The characteristics of TPOP are obviously very different from the characteristics of olive cake resulting from three-phase centrifuge systems. TPOP is a thick sludge that contains pieces of stone and pulp of the olive fruit as well as vegetation water. It has a moisture content in the range of $55 \%-70 \%$ while olive cake from a three- 
phase extraction process has only around 40\%$45 \%$ humidity (Alba et al., 2001). It also contains some residual olive oil (2\%-4\%), $2 \%$ ash with $30 \%$ potassium content

Several TPOPs coming from different treatment processes (fresh, stone-free, de-oiled and dried TPOP) were examined (Giannoutsou et al., 1997). The analysis concerned total sugars, total nitrogen, proteins, total lipids, moisture, total tannins, caloric content and $\mathrm{pH}$. The results showed that TPOP has a high content of total ash and lipids, which is understandable taking into consideration that a small quantity of the oil remains in the waste, while tannins, sugars and total nitrogen occur in lower levels (Table VIII)

TPOP also contains exploitable amounts of oleanolic and maslinic acids (Niaounakis and Halvadakis, 2004). The olive pulp cell walls contain about one third of arabinose-rich pectic polysaccharides. The L-arabinose-rich polysaccarides are named "arabinans". These polymers have a main structure of $\alpha-(1 \rightarrow 5)$-linked L-arabinofuranose units, substituted at either O-2 or O-3 or at both of these positions. The arabinans from TPOP have been isolated and characterized (Cardoso et al., 2002 and 2003).

\subsubsection{Microbial content of TPOP}

Eleven different isolates of bacteria were identified in TPOP (Niaounakis and Halvadakis, 2004). Bacillus pumilus was the most commonly found strain. The nine different isolates of yeasts were classified in four genera and eight species. The Candida genus was found to be the most predominant. Saccharomyces cerevisiae appeared at low frequency, while Candida valida showed the highest frequency. Filamentous fungi appeared at the lowest frequency. The isolates of this group were found to belong to three different genera: Rhizopus, Penicillium and Synchephalastrum and Paecilomyces. A high percentage of the isolated anaerobic bacteria seemed to be in close relation to Lactobacillus acidophilus and Bifidobacterium spp.

\subsubsection{Anaerobic digestion of TPOP}

A study of the anaerobic digestibility of TPOP at mesophilic temperature was previously reported (Borja et al., 2002). The study was carried out in a laboratory-scale completely stirred tank reactor, which was operated at influent substrate concentrations of $34.5 \mathrm{~g} \mathrm{COD/I} \mathrm{(TPOP} \mathrm{20 \% ),} 81.1$ g COD/I (TPOP 40\%), $113.1 \mathrm{~g}$ COD/I (TPOP 60\%) and $150.3 \mathrm{~g} \mathrm{COD} / \mathrm{l}$ (TPOP $80 \%$ ). The HRT varied between 40.0 and 8.3 days for the first feed used (TPOP 20\%) and between 50 and 10 days for the other three influent substrate concentrations. COD and volatile solids (VS) removal efficiencies of $88.4 \%$ and $90.9 \%$, respectively, were achieved at an organic loading rate of $12.02 \mathrm{~g} \mathrm{COD/l} \mathrm{d}$ for the most concentrated substrate used (TPOP $80 \%$ ). The maximum methane production rate was found to be 2.12 I methane/l day for the above-mentioned OLR and a HRT of 12.5 days. The system can tolerate OLRs as high as $15.03 \mathrm{~g}$ COD/l day with COD and VS removal efficiencies of $82.9 \%$ and $86.6 \%$, respectively, for this feed concentration. The methane yield coefficients were $0.30,0.27,0.23$ and 0.20 I methane STP/g COD removed for TPOP concentrations of $20 \%, 40 \%, 60 \%$ and $80 \%$, respectively.

A kinetic study of the above-mentioned anaerobic digestion process of TPOP at different concentrations demonstrated that the rates of substrate uptake and methane production were correlated with the biodegradable COD, through equations of the Michaelis-Menten type (Borja et al., 2003a). A mass (COD) balance around the reactor allowed the methane yield coefficient and cell maintenance coefficient to be obtained, which gave values of $0.25 \mathrm{I} \mathrm{CH}_{4} / \mathrm{g} \mathrm{COD}$ and 0.25 days $^{-1}$, respectively. The first one coincided with that obtained through experimental data of methane production and substrate consumption. The kinetic equations obtained and the proposed mass balance were used to simulate the anaerobic digestion process of TPOP and to obtain the theoretical COD of the reactor and methane production rates. The small deviations (equal to or

Table VIII

Characteristics of TPOP

\begin{tabular}{lcccc}
\hline & TPOP & $\begin{array}{c}\text { Stone-free } \\
\text { TPOP }\end{array}$ & $\begin{array}{c}\text { Oil reduced } \\
\text { stone-free TPOP }\end{array}$ & $\begin{array}{c}\text { Dried TPOP } \\
\left(\mathbf{4 0 0}{ }^{\circ} \mathbf{C}\right)\end{array}$ \\
\hline $\mathrm{pH}$ & 5.30 & 4.87 & 5.00 & 5.80 \\
Ash $(\% \mathrm{w} / \mathrm{w})$ & 7.10 & 7.65 & 9.12 & $\mathrm{ND}$ \\
Lipids $(\% \mathrm{w} / \mathrm{w})$ & 4.34 & 7.18 & 6.38 & 12.48 \\
Proteins $(\% \mathrm{w} / \mathrm{w})$ & 13.56 & 9.44 & 8.65 & 15.96 \\
Sugars $(\% \mathrm{w} / \mathrm{w})$ & 2.31 & 1.48 & 1.21 & 1.87 \\
Tannins $(\% \mathrm{w} / \mathrm{w})$ & 2.70 & 2.18 & 2.61 & 1.33 \\
Nitrogen $(\% \mathrm{w} / \mathrm{w})$ & 2.48 & 2.10 & 1.96 & 3.08 \\
LHV $($ Kcal/kg) & 27.61 & 15.04 & 22.45 & $\mathrm{ND}$ \\
\hline
\end{tabular}

ND: not determined; LHV: low heating value. 
lower than $10 \%$ ) between the values calculated through the model and experimental ones suggest that the proposed model predicts the behaviour of the reactor very accurately.

The results obtained in the anaerobic digestion of different concentrations of TPOP were also evaluated using the Chen-Hashimoto methane production model to determine the maximum microorganisms specific growth rate and kinetic constants of the process (Borja et al., 2003b). The above-mentioned kinetic constants were affected by the feed substrate concentration and decreased by $63 \%$ and $65 \%$, respectively, when the feed concentration increased from 34.5 to $113.1 \mathrm{~g}$ COD/I. This behaviour is believed to be due to the higher levels of phenolic compounds and biotoxicity present in the most concentrated substrate used. Methane production was reproducible within deviations of up to $10 \%$ (Borja et al., 2003b).

Another simultaneous study of anaerobic biodegradation of TPOP carried out with different concentrations, included $100 \%$ TPOP, at HRTs of between 40.0 and 8.3 days, revealed that the increase in influent substrate concentration favoured the process failure reducing the $\mathrm{pH}$ and increasing the ratio of total volatile fatty acids (VFA) to alkalinity (Borja et al., 2004). This ratio was found to be proportional to the substrate concentration $(S)$, as follows: VFA/alkalinity $=0.04(S)$. The inhibition kinetic Andrews model was used to describe the relationship between anaerobic degradation of COD and VS and the formation of methane. The values of the kinetic constants for COD removal were determined to be $28 \mathrm{~g}$ COD/l d, $27 \mathrm{~g} \mathrm{COD/l} \mathrm{and} 352$ g COD/l, respectively, for maximum substrate utilization rate $\left(R_{S \max }\right)$, saturation constant $\left(K_{S}\right)$ and inhibition constant $\left(K_{i}\right)$. Process inhibition started at COD and VS concentrations of around 20 and 18 $\mathrm{g} / \mathrm{l}$, respectively. The rates of COD removal were lower than those observed for VS removal and inhibition of VS removal occurred at a lower concentration compared to that for COD. Inhibition of methane formation started at a substrate concentration of around $17 \mathrm{~g}$ COD/I. COD and VS removal rates were higher than the rates of methane formation and these differences increased when the substrate concentration increased. This fact was underlined by the decrease of $\mathrm{pH}$, the increase of VFA/alkalinity ratio and the reduction of methane production rate.

A simplified kinetic model for studying the hydrolysis, acidogenic and methanogenic steps in the one-stage anaerobic digestion process of TPOP with a COD content of $190 \mathrm{~g} / \mathrm{l}$ was recently proposed (Borja et al., 2005a). The process was also conducted in a laboratory-scale completely stirred tank reactor at mesophilic temperature (35 ${ }^{\circ} \mathrm{C}$ ) operating at HRTs in the range of $10-50$ days. Hydrolysis and acidogenic steps prevailed at HRTs lower than 20 days, while the methanogenic step prevailed at higher HRT values. Four differential equations described the overall process. A firstorder kinetics for hydrolysis of non-soluble organic matter and a Michaelis-Menten equation type for soluble organic matter decomposition, total volatile acids consumption and methane production. The following kinetic constants with their standard deviations were obtained for the above-mentioned anaerobic stages:

(a) hydrolysis and solubilization of organic matter: $k_{1}$ (kinetic constant for non-soluble organic matter degradation): $0.054 \pm 0.003$ days $^{-1} ; k_{2}$ (maximum rate of soluble organic matter production): $4.2 \pm 0.3 \mathrm{~g}$ soluble COD (SCOD)/l d; $k_{3}$ (saturation constant): $9.8 \pm 0.5 \mathrm{~g} \mathrm{SCOD/l}$.

(b) acidogenesis: $k_{4}$ (maximum rate of soluble organic matter degradation): $3.6 \pm 0.2 \mathrm{~g} \mathrm{SCOD/l} \mathrm{d;}$ $k_{5}$ (saturation constant): $10.2 \pm 0.5 \mathrm{~g} \mathrm{SCOD//;}$ and

(c) methanogenesis: $k_{6}$ (maximum rate of total volatile fatty acids (VFA) consumption): $4.3 \pm 0.2 \mathrm{~g}$ VFA-COD/I d; $k_{7}$ (saturation constant): $3.1 \pm 0.2 \mathrm{~g}$ VFA-COD/I. The kinetic constants obtained and the proposed equations were used to simulate the different steps of the anaerobic digestion process of TPOP and to obtain the theoretical values of nonsoluble and soluble CODs, VFA and methane production. The small deviations obtained (equal to or lower than $10 \%$ ) between the theoretical and experimental values suggested that the parameters obtained represent and predict the activity of the different microorganism types involved in the overall anaerobic digestion process of this waste.

Finally, a study of the acidogenic stage of the two-stage anaerobic digestion process of TPOP was recently reported in literature (Borja et al., 2005b). This acidogenic study was carried out in a completely-mixed tank reactor at mesophilic temperature. The experimental results obtained demonstrated that the optimum value of HRT for the acidogenic fermentation process was 12 days, for which a maximum production of VFA and, specifically of acetic acid was obtained. It was found that a multicomponent substrate removal kinetic model adjusted very well to the experimental data obtained. A second-order kinetic model was used for the degradation of non-soluble COD whilst a first-order model was appropriate for studying both the total and soluble COD reduction. The values of the kinetic constants obtained were: $0.29,0.29$ and $0.12 \mathrm{~g} \mathrm{COD} / \mathrm{g}$ VSS per day for non-soluble, total and soluble COD degradation, respectively. A similar model was used to determine the kinetic constants for product formation, the order of the reaction for volatile acids production being in the range of 1.7-2.4, values very close to second order. The value of the apparent kinetic constant was minimal for acetic acid formation $(0.0009 \mathrm{~g} \mathrm{COD} / \mathrm{l} \mathrm{d})$ and maximum for valeric + caproic acids $(0.0031 \mathrm{~g}$ $\mathrm{COD} / \mathrm{l} \mathrm{d})$ because in the hydrolysis process of complex organic matter, long chain fatty acids appear first and faster than acetic acid. The kinetic model used was validated by comparing the theoretical and experimental values of the product formation rate $\left(R_{p}\right)$. The small deviations obtained suggested that the proposed model predicts the kinetics of volatile acids production accurately. 


\subsubsection{Composting of TPOP}

TPOP has been composted by Sciancalepore et al. (1995 and 1996). The quality of cured compost obtained by a mixture of crude olive cake, TPOP and fresh olive tree leaves inoculated with cow manure after six months of composting has been evaluated. The composting process brought about the total disappearance of phytotoxicity found in raw materials. The development of enzymatic activities was positive and no pathogen was found. The compost can, therefore, be satisfactorily used as an amendment for agricultural crops.

A laboratory-scale study was conducted to assess the suitability as a vermicomposting substrate of exhausted TPOP either on its own or mixed with cattle manure and/or municipal biosolids (Nogales et al., 1998). Cattle manure alone was used as a substrate for comparison. Five earthworms (Eisenia andrei) were added to $300 \mathrm{~g}$ of substrate and incubated for 17 weeks. Substrates examined were: exhausted TPOP, cattle manure, mixtures of exhausted TPOP and cattle manure (CM) (8:1 and 2:1), mixtures of exhausted TPOP and biosolids (BS) (16:1 and 8:1) and a mixture of TPOP, manure and biosolids. Where biosolids were added, pre-incubation was required to remove substances toxic for earthworms. All substrates supported the growth of earthworms and reproduction, with growth occurring for 4-8 weeks. Earthworm growth was considerably greater in the manure only substrate than in the exhausted TPOP only substrate. The addition of manure or biosolids to the exhausted TPOP enabled similar earthworm growth to that in manure only. After 17 weeks, the earthworms inoculated at the beginning of the experiment had similar biomass in all substrates. Larger weights of newly-hatched earthworms were obtained in the substrates containing exhausted TPOP. For all substrates with TPOP, vermicomposting reduced the organic carbon content, reduced the $\mathrm{C}$ : $\mathrm{N}$ considerably and also reduced the $\mathrm{pH}$. A bioassay indicated that the final products were not phytotoxic.

A further study examined the feasibility of using vermicomposting to stabilize exhausted TPOP for use as a soil amendment using cattle manure (CM) anaerobic sewage sludge (ANS) and aerobic sewage sludge (AES) co-composting agents (Nogales et al., 1998). Different ratios of TPOP to co-composting agents were examined. Earthworm (Eisenia andrei) growth, clitellum development and cocoon production were monitored over 35 days. Exhausted TPOP alone was an inadequate substrate for vermicomposting on account of slow earthworm growth and infertility. The addition of either manure or either sludge to TPOP at certain ratios enhanced worm growth and reproduction so they were generally similar to in manure only. The most effective ratios were:TPOP:CM of $2: 1$ and $1: 1$, TPOP:ANS of 16:1, 12:1 and 8:1, and TPOP:AES of $16: 1$ and $12: 1$. Vermicomposting for 35 days reduced the dry weight of the substances by $21 \%$ -
$28 \%$, and noticeably decreased their C:N. All final products had low contents of heavy metals. This study demonstrated that exhausted TPOP is a suitable medium for vermicomposting when combined with $\mathrm{N}$-rich materials such as cattle manure and sewage sludge in appropriate ratios.

\subsubsection{Integrated treatment}

García-Moreno (1998) described an integrated treatment for the purification of fresh or fermented TPOP comprising a biological treatment with pectolytic enzymes and amylase, followed by filtration and evaporation. Residual olive oil is recovered as well as a concentrate which is enriched in humic acids and mineral salts. The concentrate can be used in agriculture, as a liquid fertilizer or as a soil conditioner, or if made of fresh TPOP, in food for feeding animals.

\subsubsection{Production of alcohols and mannitol from TPOP}

TPOP contains various amounts of sugars depending on the variety of olives and the climatic conditions during growth. In a recent study, the two fractions present in the residue (olive pulp and fragmented stones) were assayed as substrate for ethanol production by the simultaneous saccharification and fermentation (SSF) process (Ballesteros et al., 2001). Pretreatment of fragmented olive stones by sulphuric acid-catalysed steam explosion was the most effective treatment for increasing enzymatic digestibility. However, a pretreatment step was not necessary to bioconvert the olive pulp into ethanol. The olive pulp and fragmented olive stones were tested by the SSF process using a fed-batch procedure. By adding the pulp three times at 24 -h intervals, $76 \%$ of the theoretical SSF yield was obtained. Experiments with fed-batch pretreated olive stones provided SSF yields significantly lower than those obtained at standard SSF procedure. The ideal SSF conditions to obtain ethanol from olive stones ( $61 \%$ of theoretical yield) were $10 \%$ substrate and addition of cellulases at 15 filter paper units/g of substrate.

In another process the extracted pulp after being subjected to a steam-explosion process, has allowed all the mannitol present therein to be separated out and recovered, which, by means of various simple purification stages (ultrafiltration, ion exchange and fractionated crystallization) permissible in the food industry, has achieved a yield with a high degree of purity (FernándezBolaños et al., 2000: Patent ES2143939, 2000).

\subsubsection{Production of hydroxytyrosol and other added-value compounds from TPOP}

A process for the value addition of TPOP that includes a hydrothermal treatment has been recently suggested (Fernández-Bolaños et al., 
2004). In this treatment an autohydrolysis process occurs and the TPOP is partially solubilized. Besides the antioxidant hydroxytyrosol several other compounds of high added value can be obtained from this water soluble fraction. Three different samples of TPOP were characterized and subjected to a hydrothermal treatment with and without an acid catalyst. The main soluble compounds after hydrolysis were represented by monosaccharides, xylose, arabinose and glucose, oligosaccharides, mannitol, and products of sugar destruction. Oligosaccharides were separated by size exclusion chromatography.

Different conditions of saturated steam in the steam-explosion process of TPOP were assayed and reported (Fernández-Bolaños et al., 2002). A high amount of hydroxytyrosol was solubilized and rose with increasing steaming temperature and time, reaching 1.4-1.7 $\mathrm{g} / 100 \mathrm{~g}$ of dry TPOP. The effect of acidic $\left(\mathrm{H}_{2} \mathrm{SO}_{4}\right)$ and basic $(\mathrm{NaOH})$ catalysts was also evaluated. Acid-catalyzed treatment was more effective at milder conditions, whereas the alkalicatalysed conditions were not very suitable. In the above-mentioned study, the extracted hydroxytyrosol was purified by means of a new, simple and inexpensive chromatographic system. From $1000 \mathrm{~kg}$ of TPOP, with $70 \%$ humidity, approximately $4.5-5 \mathrm{~kg}$ of hydroxytyrosol can be obtained. After a purification process, at least $3 \mathrm{~kg}$ of hydroxytyrosol, at $90 \%-95 \%$ purity, would be obtained. The purified compound was identified by HPLC/UV and ${ }^{1} \mathrm{H}$ and ${ }^{13} \mathrm{C}$ NMR analyses, and its antioxidant activity was tested on refined olive oil without antioxidants by the Rancimat method. The oxidative stability of refined olive oil was increased by a factor of 1.71 in the presence of 100 ppm of hydroxytyrosol.

\subsubsection{Production of furfural from TPOP}

The production of furfural by acid hydrolysis of olive stones of TPOP was recently reported (Montané et al., 2002). The hydrolysis in dilute sulphuric acid $(0.05-0.250 \mathrm{~mol} / \mathrm{l})$, at high temperature $\left(220-240^{\circ} \mathrm{C}\right)$, and short reaction times of a few minutes at the most was reported. The experimental study was performed in a tubingbomb reactor system that more or less reproduces the temperature profiles obtained in a continuous tubular reactor. Maximum furfural yields ranging from $50 \%$ to $65 \%$ of the potential were achieved depending on acid concentration and temperature.

\subsubsection{Production of activated carbon}

Activated carbons have been prepared from wastes derived from TPOP such as olive stones and solvent extracted olive pulp. The solid residues were carbonised at $850{ }^{\circ} \mathrm{C}$ and activated physically either with $\mathrm{CO}_{2}$ or steam at $800{ }^{\circ} \mathrm{C}$ (Mameri et al., 2000; Galiatsatou et al., 2001 and 2002). Another possibility of using TPOP as a raw material to produce activated carbons by chemical and physical activation has also been investigated
(Moreno-Castilla et al., 2001). In the first case, $\mathrm{KOH}$ and $\mathrm{H}_{3} \mathrm{PO}_{4}$ were used as an activating agent, and in the second case, $\mathrm{CO}_{2}$ at $840^{\circ} \mathrm{C}$ for different periods of time. The results obtained indicate that the chemical activation of TPOP with $\mathrm{KOH}$ at $800^{\circ} \mathrm{C}$, in an inert atmosphere, produced activated carbons with much lower ash content, higher nitrogen surface area and much better developed porosity than in the case of either its chemical activation with $\mathrm{H}_{3} \mathrm{PO}_{4}$ or its physical activation with $\mathrm{CO}_{2}$ at $840{ }^{\circ} \mathrm{C}$. The activated carbons can have different uses, such as absorbents in the liquid and gas phases, catalysts and support for catalysts.

\section{ACKNOWLEDGEMENTS}

The authors want to express their gratitude to the "Dirección General de Investigación", "Secretaría de Estado de Política Científica y Tecnológica" del "Ministerio de Educación y Ciencia" (Project REN2001-0472/TECNO) and "Junta de Andalucía" for providing financial support.

\section{REFERENCES}

Adams, C.E., Eckenfelder, W.W., Hoviuos, J.C. 1975. A kinetic model for design of completely-mixed activated sludge treating variable strength industrial wastewaters. Water Res. 9, 37-42.

Alba, J., Hidalgo, F., Martínez, F., Ruíz, M.A., Moyano, M.J., Borja, R. 1995. Evolución medioambiental de los sistemas de elaboración de aceite de oliva en Andalucía. Mercacei 2, 20-22

Alba, J., Hidalgo, F.J., Ruiz, M.A., Martínez, F., Moyano, M.J., Borja, R., Graciani, E., Ruiz, M.V. 2001. Elaboración de aceite de oliva virgen. In: El Cultivo del Olivo, D. Barranco, R. Fernández-Escobar, L. Rallo (Eds.), p. 551-588, Mundi-Prensa, Madrid, Spain.

Aparicio, R., Roda, L., Gutiérrez, F. 1999. Effects of various compounds on virgin olive oil stability measured by Rancimat. J. Agric. Food Chem. 47, 4150-4155.

Arienzo, M., Capasso, R. 2000. Analysis of metal cations and inorganic anions in olive oil mill waste waters by atomic absorption spectroscopy and ion chromatography. Detection of metals bound mainly to the organic polymeric fraction. J. Agric. Food Chem. 48 (4), 1405-1410.

Balice, V., Cera, O. 1984. Acidic phenolic fraction of the olive vegetation water determined by a gas chromatographic method. Grasas Aceites 35 (5), 178-180.

Ballesteros, I., Oliva, J.M., Saez, F., Ballesteros, M. 2001. Ethanol production from lignocellulosic by-products of olive oil extraction. Appl. Biochem. Biotechnol. 91-93, 237-252.

Boari, G., Brunetti, A., Passino, R., Rozzi, A. 1984. Anaerobic digestion of olive oil mill wastewaters. Agric. Wastes 10 (3), 161-175.

Borja, R., Alba, J., Martín, A., Ruiz, A., Hidalgo, F. 1993. Caracterización y digestión anaerobia de las aguas de lavado de aceite de oliva virgen. Grasas Aceites 44 (2), 85-90.

Borja, R., Alba, J., Hidalgo, F. 1994. Digestión anaerobia de las aguas de lavado de aceitunas de almazara: influencia del período de recolección sobre la cinética del proceso. Grasas Aceites 45(3), 126-131. 
Borja, R., Martín, A., Alonso, V., García, I., Banks, C.J. 1995a. Influence of different aerobic pretreatments on the kinetics of anaerobic digestion of olive mill wastewater. Water Res. 29 (2), 489-495.

Borja, R., Banks, C.J., Alba, J., Escobar, J.P. 1995b. The temperature dependence of the kinetic parameters derived for the aerobic treatment of wastewater from the washing of olives prior to the oil production process. J. Environ. Sci. Health A A30 (8), 1693-1705.

Borja, R., Alba, J., Banks, C.J. 1995c. Activated sludge treatment of wash waters derived from the purification of virgin olive oil in a new manufacturing process. $J$. Chem. Technol. Biotechnol. 64, 25-30.

Borja, R., Alba, J., Banks, C.J. 1996. Anaerobic digestion of wash waters derived from the purification of virgin olive oil using a hybrid reactor combining a filter and a sludge blanket. Process Biochem. 31 (3), 219-224.

Borja, R., Alba, J., Martín, A., Mancha, A. 1998. Influencia de la velocidad de carga orgánica sobre el proceso de digestión anaerobia de aguas de lavado de aceitunas de almazara en reactores de lecho fluidizado. Grasas Aceites 49 (1), 42-49.

Borja, R., Alba, J., Martín, A., Mancha, A. 1999. Estudio cinético del proceso de digestión anaerobia de aguas de lavado de aceitunas de almazara en reactores de mezcla completa con microorganismos inmovilizados. Grasas Aceites 50 (2) 87-93.

Borja, R., Rincón, B., Raposo, F., Alba, J., Martín, A. 2002. A study of anaerobic digestibility of two-phases olive mill solid waste (OMSW) at mesophilic temperature. Process Biochem. 38, 733-742.

Borja, R., Martín, A., Rincón, B., Raposo, F. 2003a. Kinetics for substrate utilization and methane production during the mesophilic anaerobic digestion of two-phases olive pomace (TPOP). J. Agric. Food Chem. 51 (11), 3390-3395.

Borja, R., Rincón, B., Raposo, F., Alba, J., Martín, A. 2003b. Kinetics of mesophilic anaerobic digestion of the two-phase olive mill solid waste. Biochem. Eng. J. $15,139-145$

Borja, R., Rincón, B., Raposo, F., Sánchez, E., Martín, A. 2004. Assessment of kinetic parameters for the mesophilic anaerobic biodegradation of two-phase olive pomace. Int. Biodet. Biodeg. 53, 71-78.

Borja, R., Martín, A., Sánchez, E., Rincón, B., Raposo, F. 2005a. Kinetic modelling of the hydrolysis, acidogenic and methanogenic steps in the anaerobic digestion of two-phase olive pomace (TPOP). Process Biochem. 40, 1841-1847.

Borja, R., Sánchez, E., Rincón, B., Raposo, F., Martín, M.A., Martín, A. 2005b. Study and optimisation of the anaerobic acidogenic fermentation of two-phase olive pomace. Process Biochem. 40, 281-291.

Cabrera, F., López, R., Martínez-Bordiu, A., Dupuy de Lome, E., Murillo, J.M. 1996. Land treatment of olive oil mill wastewater. Int. Biodet. Biodeg. 38 (3-4), 215-225.

Capasso, R., Cristinzio, G., Evidente, A., Scognamiglio, F. 1992. Isolation spectroscopy and selective phytotoxic effects of polyphenols from vegetable waste waters. Phytochemistry 31 (12) 4125-4128.

Cano-Agüera, F. 2004. Almazaras: depuración de aguas de lavado. En: Aguas de lavado de aceituna y aceite: procesos de tratamiento, p. 109-123, Ed. Infaoliva, Córdoba, Spain.

Cardoso, S.M., Silva, A.M.S., Coimbra, M.A. 2002. Structural characterization of the olive pomace pectic polysaccharide arabinan side chains. Carbohyd. Res. 337, 917-924.
Cardoso, S.M., Coimbra, M.A., Lopes da Silva, J.A. 2003. Calcium-mediated gelation of an olive pomace pectic extract. Carbohyd. Polym. 52, 125-133.

Cert, A., Alba, J., León, M., Moreda, W., Pérez, M.C. 1996. Effects of talc addition and operating mode on the quality and oxidative stability of virgin oil obtained by centrifugation. J. Agric. Food Chem. 44 (12), 3930-3934.

Di Giovacchino, L., Costantini, N., Serraiocco, A. Surrichio, G., Basti, C. 2001. Natural antioxidants and volatile compounds of virgin olive oils obtained by the two or three-phase centrifugal decanters. Eur. J. Lipid Sci. Technol. 103 (5), 279-285.

Di Giovacchino, L., Sestili, S., Di Vencenzo, D. 2002. Influence of olive processing on virgin olive quality. Eur. J. Lipid Sci. Technol. 104, 587-601.

Fernández-Bolaños, J., Fernández-Diez, M.J., RivasMoreno, M., Gil-Serrano, A., Pérez, T. 1983. Azúcares y polioles en aceitunas verdes III. Grasas Aceites 34, 168-171.

Fernández-Bolaños, J., Guillén, R., Rodríguez, R., Felizón, B., Heredia, A., Jiménez, A. 2000. Process for obtaining mannitol from pulp extracted from olives. Patent ES2143939 A (16-5-2000).

Fernández-Bolaños, J., Rodríguez, G., Rodríguez, R., Heredia, A., Guillén, R., Jiménez, A. 2002. Production in large quantities of highly purified hydroxytyrosol from liquid-solid waste of two-phase olive oil processing or "alperujo". J. Agric. Food Chem. 50, 6804-6811.

Fernández-Bolaños, J., Rodríguez, G., Gómez, E., Guillén, R., Jiménez, A., Heredia, A., Rodríguez, R. 2004. Total recovery of the waste of two-phase olive oil processing: isolation of added-value compounds. $J$. Agric. Food Chem. 52 (19) 5849-5855.

Fiestas, J.A., Borja, R. 1992. Use and treatment of olive mill wastewater: current situation and prospects in Spain. Grasas Aceites 43 (2) 101-106.

Galiatsatou, P., Metaxas, M., Kasselouri-Rigopoulou, V. 2001. Mesoporous activated carbon from agricultural by-products. Microchimica Acta 136, (3/4) 147-152.

Galiatsatou, P., Metaxas, M., Arapoglou, D., KasselouriRigopoulou, V. 2002. Treatment of olive mill wastewater with activated carbons from agricultural by-products. Waste Manage. 22, (7) 803-812.

García-Moreno, A. 1998. Procedimiento integral para la industrialización de alpechines y su depuración en almazaras y centros de repaso de alperujos. Patent ES2110912 A (16-02-1998).

Giannoutsou, E., Lambraki, M., Karagouni, A.D. 1997. Microbial treatment of olive mill effluents. Proc. Symp. "Olive's wastes, Kalamata, Greece, 5-8 Nov.

Gónzalez-López, J., Bellido, E., Benítez, C. 1994. Reduction of total polyphenols in olive mill wastewater by physico-chemical purification. J. Environ. Sci. Health Part A A29 (5), 851-865.

Hamdi, M. 1992. Toxicity and Biodegradability of olive mill wastewaters in batch anaerobic digestion. Appl. Biochem. Biotechnol. 37 (2), 155-163.

López-Camino, J. 1993. Evaluación de la experiencia de las plantas prototipo de depuración de alpechines en la cuenca del río Guadalquivir. Proc. IX Congreso Nacional de Química, 2, p.295-317, Sevilla, Spain.

Maestro-Durán, R., Borja, R., Martín, A., Fiestas, J.A., Alba, J. 1991. Biodegradación de los compuestos fenólicos presentes en el alpechín. Grasas Aceites $\mathbf{4 2}$ (4), 271-276.

Mameri, N., Aioueche, F., Belhocine, D., Grib, H., Lounici, H., Piron, D.L., Yahiat, Y. 2000. Preparation of activated carbon from olive solid residue. J. Chem. Technol. Biotechnol. 75 (7), 625-631. 
Martínez-Nieto, L., Rodríguez, S., Giménez, J.A., Lozano, J.L., Cobo, A., Ortega, J., Hodaifa, G. 2003. Efluentes de la industria del aceite de oliva: contribución al estudio de la composición y tratamiento de las aguas de lavado de aceituna y de lavado de aceite. En: Estudio de la composición y tratamiento como subproducto de las aguas de lavado de aceituna y aceite, p. 13-44, Ed. Infaoliva, Granada, Spain.

Martínez-Nieto, L., Rodríguez, S., Giménez, J.A., Lozano, J.L., Cobo, A., Hodaifa, G. 2004. Procesos oxidativos en el tratamiento de las aguas de lavado de aceituna y de lavado de aceite. En: Aguas de lavado de aceituna y aceite: procesos de tratamiento, p. 73-102, Ed. Infaoliva, Córdoba, Spain.

Millán, B., Lucas, R., Robles, A., García, T., Álvarez de Cienfuegos, G., Gálvez, A. 2000. A study on the microbiotica from olive-mill wastewater (OMW) disposal lagoons, with emphasis on filamentous fungi and their biodegradative potential. Microbiol. Res. 155 (3), 143-147.

Montané, D., Salvadó, J., Torras, C., Farriol, X. 2002. High-temperature dilute-acid hydrolysis of olive stones for furfural production. Biomass Bioenergy 22 295-304.

Moreno-Castilla, C., Carrasco-Marín, M., López-Ramón, M.V., Alvarez-Merino, M.A. 2001. Chemical and physical activation of olive mill waste water to produce activated carbons. Carbon 39 (9), 1415-1420.

Niaounakis, M., Halvadakis, C.P. 2004. Olive-Mill Waste Management: Literature review and Patent Survey. Typothito - George Dardanos Publications, Athens, Greece.

Nogales, R., Thompson, R., Calmet, A., Benítez, E., Gómez, M., Elvira, C. 1998. Feasibility of microcomposting residues from olive oil production obtained using two-stage centrifugation. J. Environ. Sci. Health A A33 (7), 1491-1506.

Piacquadio, P., Stefano, G., Sciancelopre, V. 1998. Quality of virgin oil extracted with the new centrifugation system using a two-phase decanter. Fet/Lipid 100 (10), 472-474.

Ranalli, A., Angerosa, F. 1996. Intregral centrifuges for olive oil extraction. The quality characteristics of products. JAOCS 73 (4), 417-422.
Raposo, F., Borja, R., Sánchez, E., Martín, M.A., Martín, A. 2003. Inhibition kinetics of overall substrate and phenolics removal during the anaerobic digestion of two-phase olive mill effluents (TPOME) in suspended and immobilized cell reactors. Process Biochem, $\mathbf{3 9}$ 425-435.

Raposo, F., Borja, R., Sánchez, E., Martín, M.A., Martín, A. 2004. Performance and kinetic evaluation of the anaerobic digestion of two-phase olive mill effluents in reactors with suspended and immobilized biomass. Water Res. 38, 2017-2026.

Raposo, F., Borja, R., Sánchez, E., Martín, A. 2005. A kinetic evaluation of the anaerobic digestion of twophase olive mill effluent in batch reactors. J. Chem. Technol. Biotechnol, 80, 241-250.

Rodríguez, M.M., Pérez, J., Ramos-Cormenzana, A. Martínez, J. 1988. Effect of extracts obtained from olive oil mill waste on Bacillus megaterium ATCC 33085. J. Appl. Bacteriol 64, 219-222.

Sciancalepore, V., Colangelo, M., Sorlini, C., Ranalli, G. 1995. Compostaggio in ambiente protetto del residuo della lavorazione delle olive con impianti ad estrazioni bifásica. Ingegneria Ambientale 24, 11-12.

Sciancalepore, V., Colangelo, M., Sorlini, C., Ranalli, G. 1996. Composting of effluent from a new two-phase centrifuge olive mill. Microbial characterization of the compost. Toxicol. Environ. Chem. 55 (1-4), 145-158.

Servili, M., Baldioli, M., Selvaggini, R., Miniati, E., Machioni A., Montedoro, G. 1999. High performance liquid chromatography evaluation of phenols in olive fruit, virgin oil, vegetation waters and pomace in 1Dand 2D Nuclear Magnetic Resonance characterization. JAOCS 76 (7), 873-882.

Tsonis, S.P., Tsola, V.P., Grigoropoulos, S.G. 1987. Systematic characterization and chemical treatment of olive oil mill wastewater. Toxicol. Environ. Chem. 2021, 437-457.

Wheatley, A. (1990). Anaerobic digestion: a waste treatment technology. London, UK: SCl, Elsevier.

Recibido: Septiembre 2005 Aceptado: Noviembre 2005 